\title{
Educational Activities in Civil Society
}

\author{
Dana Moree and Terezie Vávrová
}

\section{1 \\ Introduction}

According to annual studies conducted by the Czech NGO People in Need many Czech high schools' students are not interested in public issues and don't want to engage in their future civic life (JSNŠ, 2017). In addition, most students don't feel equipped with any kind of civic skills, neither they believe they can change anything in the society of which they live. Such disbelief and low selfefficacy (Bandura, 1997) proves that the Czech educational system doesn't offer enough opportunities to learn civic skills and train those in a safe space of school.

Even though citizenship education is a separate subject prescribed by the Czech National Curriculum, this subject and the way it is actually taught and doesn't meet current educational demands of its students and society in general. The formal approaches are still quite common or rather of a classical standard. The slackening results of Czech students in national and international studies (ICCS, 2009; JSNŠ, 2017) have shown that the current practice is not enough to produce the desired outcomes. Citizenship education despite its importance has a rather low status in Czech schools. Compared to the natural sciences, learning civic skills is perceived as less worthy by students. Also apparently, teachers in the Czech Republic fail to mediate the importance of citizenship education for the world and society outside of school as the Teaching Common Values study showed (Veugelers, De Groot, \& Stolk, 2017).

A big contribution to overcoming this educational challenge is the civil society. Many teachers value the fruitful cooperation with NGOs which represent a popular source for new approaches and activities offered to schools for free. These NGOs manage to choose methods related to real-life situations that played out in the school, community or the wider world. Linking subject matter with real life can create greater interest and motivation amongst students to engage in discussions about these specific issues. So NGos arrange mock elections and discussions with witnesses of certain period (e.g. holocaust survivors), offer ready-to-use tools, such as, short documentary films, or adopt international know-how to the Czech context (e.g. in storytelling, philosophy for children, or Theatre of the Oppressed). 
In the following, we explain the theoretical and empirical background of the module and the programme of the module itself. First however, we briefly introduce the Czech education system, and the impact of existing policies on the ability of academic staff and students to advance citizenship education in the country. We link this to the needs of university education and how the Theatre of the Oppressed approach can respond to those needs. Finally, we describe the Czech EDIC module, its development, current schedule and perception of students.

The development of the educational system in the Czech Republic mostly followed as a consequence of the reaction to political changes in 1989. After this breaking point, we see increasing openness in Czech society, but also a certain amount of inertia. For example, the school act from 1984 was valid up until 2004, when the first significant change took place. The main feature of the education system during communism was that all its parts were subordinated towards political goals. First, the state had control over the types of schools (Kozakiewicz, 1992). It was impossible to found a private or church-led school because the state was the only authority which could take this legal step. Consequently, the state had strong control over the content of education, including textbooks and teachers (Tomusk, 2001). Moreover, students of the pedagogical faculties were very carefully chosen based on their "personal background" and loyalty towards the regime.

After 1989, the main change came with the educational reform in 2004 that brought significant changes through several levels of the system. The educational system was decentralised, and it began to propose broader educational contents (rather than exactly prescribing specific topics for each class) and introduced the idea of key competences. The schools themselves were given increasing freedom but also responsibility for preparing the so-called School Educational Programme based on national guidelines. Its implementation process, however, was insufficiently funded and teachers' salaries still remain very low today.

On the curriculum level, the reform brought two essential changes compared to the previous school system. First, the results of the teaching and learning process are no longer assessed only by the amount of cognitive information gained by students (which was very much the case in previous curricular documents), but also by the broader competences developed. The curriculum for attaining these competences is divided into two levels. Level 
one covers educational areas (e.g. language and communication, mathematics and its application, the human being and society), while level two covers the so-called cross-curricular educational topics, implying social skills education, awareness of the European and global context, multicultural education, environmental education and media education (Research Institute of Education in Prague, 2007). Cross-curricular topics penetrate all subjects and areas. This is what is known as the 'infusion model' (Anderson, MacPhee, \& Govan, 2000).

The vast majority of primary schools and high schools in Czech Republic are state institutions, although quite a big number of private and church-led schools have been established since 1989. While the 9 years of primary schooling are compulsory, the secondary level of education is voluntary. The main types/tracks of secondary education are grammar schools, and pre-vocational schools or 'expert schools', oriented towards trade, agriculture, etc. Decentralisation of the educational system in 2004 thus brought more freedom to schools and teachers, but at the same time also plenty of confusion and practical problems maintaining schools 'above the standard level'. Citizenship was amongst the areas most affected by these issues.

The Czech schooling tradition emphasises teaching citizenship as a separate compulsory subject (more in Veugelers, de Groot, \& Stolk, 2017). Next to it, schools can use the opportunity to implement citizenship issues in all subjects as cross-curricular topics. However, more precise criteria for evaluating and assessing these learning outcomes are still missing. The state has not shown interest in creating criteria and collecting data on the effectiveness of citizenship education in Czech schools, only participating in the ICCS study in 2009. Since than it remains to the civil society to find out about the current state of citizenship in Czech schools and the results are alarming.

Recent studies indicate that schools have significant problems educating and training young citizens (JSNŠ, 2017; ICCS, 2009). Why so? Teachers typically manage to pass on knowledge, but don't know how to deal with values and skills. Also to teach those two areas can't be evaluated easily and needs more time. So, the productive step is to cooperate with NGOS which have specific educational know-how and offer students experience-based, skilloriented learning.

Therefore, the cooperation of NGOS and schools in educating and training young citizens is the main topic of the presented module that aims to provide students with in-depth insight into the work of NGO's, by visiting and analysing concrete projects in light of relevant literature. This aim is attained via two approaches. First, experts from NGOs will be invited into the EDIC course and students will be able to observe and experience some concrete 
activities of NGOs during field trips. Second, a significant part of the course will be based on theatre of the oppressed methodology, where students will work together with "people outside of university" - NGO workers and their clients in our case. With the module, the students will take away not only a deeper knowledge about NGOs - what kind of citizens those intend to educate in schools and how they do this - but they will also experience the direct outreach to the community.

\subsection{Theoretical Background}

The above mentioned situation is especially relevant for primary and secondary schools. However, universities deal with their own issues. Universities and high schools face new situation given by reform articulated in Act 137/2016 in the Czech Republic. One of the results of this reform is that the universities would be divided into those, which are more practically oriented and those, which are more academically oriented.

Universities perceived, as so called academic oriented, produce rather practically oriented graduates, e.g. disciplines like pedagogy, social work, special pedagogy and others. At the same, time we can see these universities face an increasing tendency to be reduced to producers of high achieving academic publications, where international competition is seen as more and more important than anything else. Academic achievement is highly followed and rated in the university, pedagogical interaction with students, teaching and learning culture, school culture and other soft aspects of education are rated insufficiently or not at all. This manifests a dilemma for the teaching staff as they are pushed to focus on academic achievement.

When we look at the same issue from the perspective of students, we can see their pressing needs. Those university students are prepared, amongst others, to also work with a wide range of disadvantaged children and adults. E.g. Charles University provides possibilities to study pedagogy, special pedagogy, social work, psychology or civil society, which are disciplines that go hand in hand with social justice, equality and inequality in the society. Skills necessary for working in these professions are not only transmitted by studying theory, but by also working with people directly, by analyzing issues related to social injustice, intercultural issues, democratic citizenship and others. When we look at the composition of students in university environment, we can see that universities world-wide often reproduce power differences in societies (Mann, 2008). Students with different social or ethnic background are still underrepresented (Ghofa, 2017; Mann, 2008). This is also the case in the Czech Republic where minority students are underrepresented and the majority of university students have very limited experiences with minority groups. 
This situation has several consequences. Students in Pedagogy and social work, who will typically work with a disadvantaged population after graduation, have limited possibilities to engage with such people in their daily lives. This is given by students' community composition. The same students study at least at part of universities theoretically oriented disciplines, which do not provide sufficient practical training or other kind of activities, which would help to address this lack of experience. Moreover, students come to a situation, where they are perceived as passive absorbers of curricula, which are given by difficult system of accreditations (Mann, 2008). And they do not experience many possibilities to change their own educational environment and the means in which they learn.

We know how the learning process should look if we want to prepare professionals who are not only experts equipped with theoretical knowledge but also skilled people able to reflect, make decisions and react properly in difficult situations. Scholars like Dewey (1938), Freire (1974), Oser and Veugelers (2008), and others brought enough evidence regarding the necessity to create nurturing learning environment, as well, as ideas how to develop such environment. We can see that many scholars around the world try to react to this situation, to bring and test new methods, which would help to cross this gap between the privileged and competitive university world and parts of the society with a higher amount of disadvantaged population.

Theatre of the Oppressed is perceived as one of the methods, which might serve to these goals (Christensen, 2014; Desai, 2017; Giesler, 2017; Stahl, 2018). Charles University of Prague started to implement this method several years ago. Experiences have so far indicated that Theatre of the Oppressed (TotO) is a valuable source for fostering intercultural competences in students, it was included into the module for EDIC. In the next section, we introduce the method: we first explain the path which led our university to use TotO as one of the teaching methods, and introduce TotO with practical and ethical issues that need to be taken into account. We then discuss some advantages and limits regarding TotO implementation at the universities, and its potential for research. Then, we will describe more concretely how Theatre of the Oppressed is implemented in Charles University of Prague.

\subsection{Path to the Theatre of the Oppressed}

Theatre of the Oppressed has been inherently linked to university environment for about ten years in the Czech Republic. The so-called Cabinet for Theatre of the Oppressed [Kabinet divadla utlačovaných] was founded at Masaryk University in Brno. It took however several years for the method to spread across Czech Republic. The Department of Civil Society at Faculty of Humanities, 
Charles University began promoting the method in 2014 when the Training for Trainers was organized in cooperation with British Council. This event put the faculty in an 'expert role' for the Theatre of the Oppressed method.

When new topics, e. g. multicultural education, citizenship education and environmental education were introduced as a part of the school reform of 2004, teachers were not prepared for this, due to these disciplines being quite new in the Czech context (Moree, 2008) while concurrently embodying a sense of resistance. Teaching, which would be oriented towards changes of attitudes, reminded teachers too much of the ideological utilization of the education system prior to 1989 (Moree, 2013).

Faculty of Humanities tried to support school reform utilizing several activities. One activity being the development of Czech Kid, a teaching tool for multicultural education based on stories of children. (www.czechkid.cz). This tool offers an introduction to more than 6o topics linked to multicultural education, more than 400 pages of theoretical material written in a way which is acceptable for teachers and roughly 6o suggestions for concrete teaching lessons. Czech Kid was introduced in 2007 as a low-threshold internet tool that can be used by teachers without formal training.

Next to these supportive materials, it was clear that working with concrete groups would encourage people to discuss topics which are taboo in society, such as, discrimination, racism or sexual abuse. Theatre of the Oppressed was introduced through training led by Terry O'Learry of Cardboard Citizens in London, since noone in Czech Republic was qualified train the trainers in this method. Twenty participants were trained, opening the door to also implement the method at the university.

\subsection{Theatre of the Oppressed at Universities}

Theatre of the Oppressed is a method to start a dialogue about possible social change. It was created by Augusto Boal in Brazil almost fifty years ago and spread all over the world. Its main aim was to provoke societal change and empower the disadvantaged (Conrad, 2004; Christensen, 2014; Saeed, 2015; Desai, 2017; Giesler, 2017; Stahl, 2018). As such, the method is inherently linked to critical pedagogical approaches. Practically, it works as follows:

A group of people having an experience of un-just, troubles, difficulties or oppression work together utilizing a wide range of methods promoting the ability to re-call their experiences, to express them through their body and incarnate previous experiences into a new story, which is translated into theatrical language. This specific methodology is described by Augusto Boal and his followers in many books (Boal, 1979, 1992). 
When the theatre piece is ready, it is performed in front of the audience, which is not allowed to be a passive absorber of the given story. The audience is asked to change it. Audience members are invited the stage to solve the protagonist's issue. This stage of group work is called 'forum theatre'.

TotO was originally targeted to work with disadvantaged groups in slums, prisons, ghettos etc. (Boal 1979, 1992), thought Augusto Boal later adapted this methodology to work with more fortunate people, who do not experience external oppression (like being beaten on the street), but who experience internal oppression derived from possible societal, family or institutional pressure. Shortly thereafter, he developed methods to cope with any form social pressure. This method was called Rainbow of Desire and is perceived as therapeutic method (Boal, 1995).

Theatre of the Oppressed is implemented in different countries by a wide range of institutions and for various target groups. In some countries, there are NGOS working for a long time with one target group by means of this method (e.g. Cardboard Citizens in the UK has worked for more than 25 years with homeless people or Kurunga center in Berlin working with gender issues). There are centers of Theatre of the Oppressed in many countries in the world with NGOs or independent groups of trainers using TotO only as one of their daily activities.

By implementing TotO, the teaching staff may help students bridge the gap between theory and practice, and between privileged students and underprivileged members of society. However, TotO come with ethical and practical issues. As we mentioned above, the university environment is in fact a privileged environment. It does not mean that students cannot experience oppression. The opposite is true - we know e.g. that a significant volume of students experience some kind of sexual harassment (Christensen, 2014). Do note, this form of oppression is different than oppression seen in disadvantaged societal areas.

Moreover, university environment is hierarchical. Teachers are owners of credits, set the conditions of classes, and there is not much space for negotiation with the students. Methods like Theatre of the Oppressed requires the opposite - an abundance of safe space for negotiation and a nurturing environment (Stahl, 2018), which might be contradictory to requirements of university studies.

Sensitive issue can be treated carefully when they emerge by asking several questions: who is going to participate, how is the participation defined and what is the result of the Theatre of the Oppressed implementation. We can look at these questions step by step: 
- Who is going to participate - in many of published studies, only university students became participants of the Theatre of the Oppressed groups (Desai, 2017; Stahl, 2018), which definitely has many advantages - students know each other and it is easier to create a safe space in well-known environment. However, at the same time, disadvantaged groups are still underrepresented.

- How is participation defined - if the Theatre of the Oppressed is offered as a course, students have to fulfill the prescribed requirements (e. g. participation) of the course. The ethical issue is how to react in situation when the topic is too sensitive (Stahl, 2018) and when working on these sensitive issues can harm the students.

- What is the result of implementing the Theatre of the Oppressed - the original method leads to public performance, which is called forum theatre. Audiences can visit the performance and react, try to change the destiny of the main protagonist and provoke social change. Is participation in a performance an obligatory part of Theatre of the Oppressed group at the university?

Being aware of these questions, we started to implement Theatre of the Oppressed at Charles university since 2015 (Moree, Vavrova \& Felcmanová, 2017). A group of university students work together with clients or members of some NGO or any other disadvantaged group (like minority groups, people with refugee's experiences etc.). The basic course leads to formulating the problem of the group and creating the basic line of a new story. Then, students as well as other participants, may decide if they want to perform publicly or not.

\subsection{Theatre of the Oppressed as a Research Method}

Theatre of the Oppressed was not originally created as a research method. It is a method, aimed at social change, transformation of the experience of the oppressed individuals and groups, and empowerment. However, working by means of this method is highly intensive and the work generates deep insight into a problem, which the group solves. Then it is logical that it attracts researchers to make a use of available data. Research on, and of, Theatre of the Oppressed performances is generally defined as action research (Lewin, 1946). The group process is described in detail and results and reflection of its participants are shared (Call-Cummings \& James, 2015).

At the Charles University of Prague, we also applied this strategy for several years, but due to the fact that we worked with a mixed group, it appeared to be insufficient. Reasoning being, we often faced situations in which tiny reinterpretation of concepts happened as a side product of the group process. And the same theory created by the group was tested and redefined during the interaction with the audience. We often saw data from our mixed groups that they went further than we were able to capture by action research. It was 
more similar to research analyzing these tiny reinterpretations like those by Yanov \& van der Hart (2013), but we were not able to catch the subtle moments by action research methodology.

It led us to look for new research designs, which would be useful for this kind of groups. In the end we used a mixed methodology divided into two stages:

Stage 1 - preparation of the theatre performance. This stage started to be perceived as a process of formulating research question, where the group of participants formulates the question. We started to use ethnography based on field notes in this stage.

Stage 2 - performing with the audience. This stage began to be perceived as collecting data, which should answer research question formulated in stage 1 . We taped the performances and coded audience created combined with field notes of the teachers.

Theatre of the Oppressed is now used within our faculty in a myriad ways:

- University offers a course on Theatre of the Oppressed where students work together with representatives of target groups outside the university. By those means ca. two theatre performances are made every academic year. Students cooperated with a broad demographic of people outside university like Roma, Vietnamese immigrants and representatives of other minority groups. Topics chosen were e.g. sexual abuse at school, discrimination, racism and sexism.

- Performances are available online - every performance is advertised on theatre web pages and outside institutions can order these performances. We have co-operated with several institutions like schools, NGOs, festivals and conferences.

- In collaboration with NGO's performances are used in some trainings and seminars - in the last two years the performances became regular part of trainings for teachers organized by NGOS, trainings for teachers in kindergartens or for American students coming for a term to the Czech Republic.

Combination of these approaches is used also in EDIC module.

The EDIC module is implemented at the department of Civil Society, Faculty of Humanities, Charles University. Before the production and implementation 
of the module started, there were several preparation activities in last years. The department has a close link to NGOs from the very beginning. Guests from various NGOS participated in teaching while providing their own expertise. The department perceives the lack of practical training at the university level of education and therefore, it strives for a difference. Practical learning is an inherent part of the studying program and students must choice how they will spent 107 hours of practical training. The Department of Civil Society is not a place for pre-service teacher preparation and in such, the topic of education was not been explicitly threaded into the program from its inception. However, when the School reform act was introduced in 2004, NG Os started to play a service role for schools (Moree, 2010). Teachers were not experts at implementing so called cross-curricula themes and NGOs were very often quickly able to offer programs for schools. However, the quality of their programs varied (Moree, 2010).

Differences in quality was a leading reason to implement a new course on Education and civil society in 2015. The course composed of faculty teachers, as well as, external teachers and trainers, and provided students with theoretical background with concrete strategies, promoting democratic citizenship education in schools. This course became a source of inspiration while preparing the EDIC module with Theatre of the Oppressed activities of the same department. In the EDIC module, we combined these two approaches and build upon previous experience.

\subsection{Description of the Module}

When we look at the module concretely, we can see that it further develops activities started by the Faculty of Humanities (at Charles University), placing them in an international context to bring them closer to citizenship education in schools. We make use of the concept of the 'Theatre of the Oppressed' (Boalo, 1992), additionally drawing from previous research from the field of education and transformation of society after the fall of communism (Moree, 2008, 2013). We further elaborated in the directions mentioned below.

In particular, the course reflects on citizenship education in the light of societal changes over the last twenty years, specifically focusing on the following topics:

1. We analyse the extent to which education and civil society is linked to the societal context with a special focus on the transformation from communism to a more open system. An important aspect the module is the cooperation between civil society and schools (Kymlicka, 2001; Parker, 2007).

2. In the course, we analyse particular cases where civil society and NGOS help schools with citizenship education. We work and research via 
concrete examples of several projects or disciplines such as multicultural education, history and citizenship education, school parliaments, etc. This part of the course is based on an interdisciplinary approach (Banks, 2004; Moree, 2008; Osler \& Starkey, 2010; Anthias, 2011).

3. Finally, we analyse empowerment and oppression as part of citizenship education. We believe through this method, we can create a more critical and engaged democratic citizenship. The 'Theatre of the Oppressed' is the main method of this part of the module.

The module combines several teaching and learning methods: literature analyses and presentations are combined with interactive learning, dialogical learning, field visits and personal reflections. Dividing the module into two parts, the first being dedicated to citizenship education in Czech Republic and what role do the NG Os play in it. We organize field trips and observe concrete activities and approaches the NGOs do in, for and with schools. Students apply literature and theoretical concepts discussed in the class to their experience in NGOs and critically discuss their ideas together. The second part is a bloc seminar of Theatre of the Oppressed methodology where a story based on observed pressing issues is prepared. Afterwards, the students decide whether they want to perform the story or not. Usually they do, so the module is crowned with this performance of participatory forum theatre and discussion of the topic with the audience.

\subsection{NGO as Key Agents for Citizenship Education in Schools}

Cooperation with NGOs is an inevitable part of the course and it is realised by several means. First, there are planned excursions to NGOs with long-term links to the Department of Civil Society who operate directly with schools. Therefore, these NGOS are educational agents, bringing citizenship education topics to school environments.

- Pragulic is an NGO working with homeless people who guide tours around Prague. Routes or particular tours are linked to the life story of the guide. This NGO was founded by students and graduates of the Department of Civil Society. Its activities show how marginalized people can experience empowerment through storytelling while concurrently creating work opportunities. Tours are offered to schools as well.

Students learn how to work with marginalized groups on topics of social (in)justice and citizens empowerment, including how to address difficult topics with pupils and school audiences.

- CEDU - Centre for democratic learning works with school parliaments. It is another NGo linked to the Department of Civil Society as two PhD students of the NGO were involved in the module and its predecessors from the very beginning. 
CEDU operates directly in schools, therefore students of the EDIC course observe activities of this NGO, experience school council meeting and how this tool foster active citizenship between involved pupils.

- Other Ngos linked to minority issues include Slovo 21, Ara Art and InBáze. All are integrated in the module, all organize seminars focused on multicultural education, and opening dialogue in controversial issues in schools. Students observe direct work of the groups of pupils and lead some activities themselves.

Adding, the Theatre of the Oppressed is always organised in cooperation between module students and people linked to NGOs. One limitation is the language barrier, due to the module's offering in English. This issue is solved by working together with NGOs whose staff members or clients are able to speak at a minimum, an elementary level of English. Basic English is a necessary condition for basic communication between all participants of the theatre. Therefore, we perceive the EDIC module as an opportunity and the international group of students have an advantage as English is more natural for these groups.

Cooperation with NGOs is reflected in the final paper which links theory to practice. By the end of the course, students produce a final paper where they choose to elaborate and reflect on one of their experiences from the field (excursion or Theatre of the Oppressed) in the light of theories which they studied in the first (theoretical) part of the module.

\section{$4 \quad$ Syllabus}

\subsection{Aims of the Module}

After completing the module, students have:

- Knowledge of the education system and civil society in the Czech Republic, an overview of current standing of citizenship education in Czech schools.

- Knowledge of educational activities in various Czech NGOs in schools.

- Skills and methods to perform and analyse field observation from the perspective of introduced theoretical concepts.

- Skills to apply theoretical concepts to different practices.

- Skills to engage with Theatre of the Oppressed - empathy, team-work, critical thinking and presenting.

\subsection{Sessions Schedule}

1. Education system and civil society in the Czech Republic

- Transformation of Czech society and educational reforms

- Cross-curricula themes and NGOs 
2. Citizenship Education

- History, recent developments and practices

- Human rights and education in post-totalitarian society

- Human rights and education in regions with open conflicts

3. History and its reflection

- Narratives of unjust and modern history in schools

- Activities of NGOs in the field

4. Oppression and empowerment - bloc seminar with students-refugees, who came to the Czech Republic without parents

- Theatre of the Oppressed - students preparing theatre performance together with representatives of marginalized groups.

- Research among and with marginalized groups

5. Citizenship Education, inclusion and moral

- Citizenship and special education

- Citizenship education in inclusive school context

- Being citizen with special educational needs or similar topics

6. Active citizenship and activities initiated in schools by NGOS

- Participation in schools

- School Parliaments

- One World festival at schools

7. Oppression and empowerment - bloc seminar with students-refugees, who came to the Czech Republic without parents

8. NGO activities in the field of education

- Different NGo projects (Pragulic, Antikomplex, Slovo 21, Centre for Citizenship Education and ARA ART)

- Field trips

- Field observations

- Presentations

9. Theatre of the oppressed performance

\subsection{Assessment 7 EcTs}

- Active participation in the contact teaching activities and Theatre of the Oppressed. 
- Final paper - reflection of one activity of the course from the perspective of theoretical concepts, which were introduced (minimum 5 references).

\section{$5 \quad$ Conclusions}

The aim of the module is to focus on the role of NGOs in citizenship education in the formal environment of schools, fulfilled by three steps. First, students talk to NGOs operating in the field of their motivation, vision and best practices. That step brings deeper knowledge and understanding of what is going on in schools, what are the needs of the Czech educational system concerning citizenship.

Meetings with representatives of NGOs opened my eyes. I did not know what the current school situation looks like and I have never experienced a similar lesson on citizenship. So much can be done! The course helped me clarify the role of the civic sector in the education system and how we - future NGO staff - can participate in the education of future citizens. (Student of the course)

While observing the NGO's educational activities students think through the topics and reflect on the educational moments they witnessed, and learn research methods to describe, analyse and evaluate what they saw during the field trips.

I learned to look more critically and take field notes. This I have found very helpful for my future studies. (Student of the course)

Finally, students have the opportunity to participate in the process based on Theatre of the Oppressed methodology and together with NG Os'representatives (employees as well as clients), they create a story which addresses their pressing issues connected to education and previous experience.

I got a lot of emotions out of myself. After the weekend, when I played the aggressors, I noticed I was much calmer. I always exploded at the theatre, but afterwards, I was never angry. It's psychohygienic. The theatre meetings provide us with a nice space where we can be entrusted, even if we know each other only for a moment. It is a powerful experience when you step on stage to perform in front of the audience and hear all of their suggestions. This is how social change can be achieved! (Student and actor of the theatre) 
There are several reasons why we work by means of combining the above mentioned methods and goals. Universities play an inevitable role in preparing professionals to work with disadvantaged groups. Their graduates need theoretical knowledge and a deep understanding of the topics they will support. At the same time, they need not only experience with disadvantaged people, but also relationships uninfluenced by power differences. These are main reasons leading us to combine academic means of working and thinking with tools to create space for new equal relations.

The goals we want to achieve are two-folded. We would like to create an open environment for student reflection so they are able to attain deep insight into what they do and why they do it. At the same time, we try to enlarge tools leading to empowerment, which students can not only use in the module, but also in their future professional work. Theatre of the Oppressed is a strong tool, which creates new memories, new type of experiences and new skills to cope with difficult situations. Performing together with those labeled as disadvantaged may become a moment in which people open themselves for new ways of thinking and even living.

\section{Acknowledgement}

This publication was supported by the Ministry of Education, Youth and Sports Institutional Support for Longterm Development of Research Organizations Charles University, Faculty of Humanities (2018).

\section{References}

Anderson, S., MacPhee, D., \& Govan, D. (2000). Infusion of multicultural issues in curricula: A student perspective. Innovative Higher Education, 25, 37-57.

Anthias, F. (2011). Intersections and translocations: New paradigms for thinking about cultural diversity and social identities. European Educational Research Journal, 10, 204-216.

Bandura, A. (1997). Self-efficacy: The exercise of control. New York, NY: Freeman.

Banks, J. (Ed.). (2004). Diversity and citizenship education; Global perspectives. San Francisco, CA: Jossey-Bass.

Boal, A. (1979). The theatre of the oppressed. New York, NY: Urizen Books.

Boal, A. (1992). Games for actors and non-actors. New York, NY: Routledge Press.

Boal, A. (1995). The rainbow of desire. London: Routledge.

Call-Cummings, M., \& Christine, J. (2015). Empowerment for whom? Empowerment for what? Lessons from a participatory action research project. Networks: An Online Journal for Teacher Research, $17(2)$. 
Christensen, M. (2014). Engaging theatre for social change to address sexual violence on a college campus. British Journal of Social Work, 44, 1454-1471.

Conrad, D. (2004). Exploring risky youth xxperiences: Popular theatre as a participatory, performative research method. International Journal of Qualitative Methods. Retrieved from http://ejournals.library.ualberta.ca/index.php/IJQM/article/viewFile/ $4482 / 3787$

Desai Shiv, R. (2017). Utilizing theatre of the oppressed within teacher education to create emancipatory teachers. Multicultural Perspectives, 19(4), 229-233.

Dewey, J. (1938). Experience and education. New York, NY: KappaDelta PI.

Freire, P. (1974). Education: The practice of freedom. Santiago: Institute for Agricultural Reform.

Giesler, M. (2017). Teaching note - Theatre of the oppressed and social work education: Radicalizing the practice classroom. Journal of Social Work Education, 53(2), 347-353.

Gkofa, P. (2017). Promoting social justice and enhancing educational success: Suggestions from twenty educationally successful Roma in Greece. Urban Review, 49, 498-509.

ICCS. (2009). In P. Soukup (Ed.), Národní zpráva z Mezinárodní studie občanskérýchovy [National report on international study of civics]. Praha: Ústav pro informace ve vzdělávání.

JSNŠ. (2017). Jeden svět na školách: Zpráva o dotazníkovém šetření na středních školách z roku 2017 včetně porovnání s rokem 2014, 2012 a 2009 [One world at schools: Report on survey in secondary Schools from 2017]. Praha.

Kozakiewicz, M. (1994). The difficult road to educational pluralism in Central and Eastern Europe. European Education, Fall, 1994.

Kymlicka, W. (2001). Politics in vernacular: Nationalism, multiculturalism and citizenship. Oxford University Press.

Mann, S. (2008). Study, power and the university: The institution and its effects on learning. New York, NY: McGraw-Hill Education.

Moree, D. (2008). How Teachers Cope with Social and Educational Transformation; Struggling with multicultural education in the Czech classroom. Utrecht: University of Humanistic Studies.

Moree, D. (2013). Učitelé na vlnách transformace; kultura školy před rokem 1989 a po něm [Teachers on the waves of transformation: School culture before and after 1989]. Praha: Karolinum.

Moree, D. (2016). Leaving a trail: Sense of life and women's activism. Communio Viatorum, LVIII, 1, 94-116.

Moree, D., Vávrová, T., \& Felcmanová, A. (2017). Blue or red, why do categories attract? Urban Review.

Moree, D. (2010). Organizace občanské společnosti a multikulturní výchova v České republice. (NGOs and multicultural education in the Czech Republic) 
In M. Skovajsa (Ed.), Občanský sektor; organizovaná občanská společnost v České republice [Civil society sector; Organised civil society in the Czech Republic].

Oser, F., \& Veugelers, W. (Eds.). (2008). Getting Involved; Global citizenship development and sources of moral values. Rotterdam, The Netherlands: Sense Publishers.

Osler, A., \& Starkey, H. (2010) Teachers and human rights education. London: Trentam Books.

Parker, W. (2007). Imagining a cosmopolitan curriculum. A working paper developed for the Washington State Council for the Social Studies. Seattle, WA: University of Washington.

Saeed, H. (2015). Empowering unheard voices through theatre of the oppressed: Reflections on the legislative theatre project for women in Afghanistan.Journal of Human Rights Practice, 7(2), 299-326.

Skovajsa, M. (2010) Občanský sektor: Organizovaná občanská společnost v České republice [Civil society sector; Organised civil society in the Czech Republic]. Praha: Portál.

Stahl, S. (2018). Acting out to call in: Practicing theatre of the oppressed with high school students. The Educational Forum, 82, 369-373.

Tomusk, V. (2001). Enlightenment and minority cultures: Central and East European higher education reform ten years later. Higher Education Policy, 14, 61-73.

Veugelers, W., De Groot, I., \& Stolk, V. (2017). Research for cult committee - Teaching common values in Europe. Brussels: European Parliament, Policy Department for Structural and Cohesion Policy. Retrieved from http://bit.ly/2pm5Yh9

Yanov, D., \& van der Hart, M. (2013). People out of place: allochthony and autochthony in the Netherlands' identity discourse - Metaphors and categories in action.Journal of International Relations and Development, 16, 227-261. 